\title{
THE DETECTION OF $\beta$-OXYBUTYRIC ACID IN THE URINE.
}

\author{
By T. Stunft Hart, A.M., M.D.,

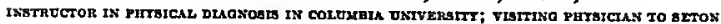 \\ HDarres, sew yoss:
}

IN a considerahle numher of diseases, notahly in diahetes mellitus, the detection of $\beta$-oxyhutyric acid is of great interest and of importance both from a diagnostic and therapeutic standpoint. The statement, repeated in a numher of text-books on chemical diagnosis, to the effect "that when a urine, which has been fermented, deviates the plane of polarized light to the left, the presence of $\beta$-oxyhutyric acid may be inferred," is certainly hesitating enough to leave some douht in our minds as to this mode of detection. This doubt is augmented when we review the list of suhstances at times found in the urine which may produce the same effect. Among those most frequently encountered may he mentioned creatinin and various compounds of glycuronic acid. Also certain compounds of lead, which are formed when lead acetate is added in the process of clearing urine for examination in the spectroseope, have been shown by Magnus-Levy' to possess a marked levorotatory action.

It is not for lack of methods for the detection of $\beta$-oxybutyric acid that I venture to suggest a new one. Procedures have heen worked out hy a large number of investigators-Tollens, ${ }^{2}$ Wolpes, ${ }^{3}$ Naunyn," Stadelman," Magnus-Levy," Bergell," Darmstäder," Waldvogel," Shaffer, ${ }^{10}$ and Black. ${ }^{11}$ Some of these metbods are adapted to the quantitative as well as the qualitative determinations of $\beta$-oxy: butyric acid, some of them bave serious defects, practically all are laborious cbemical procedures which require many bours of work, the facilitics of a well-equipped laboratory, and the manipulations of a skilled chemist. Parenthetically it may he said that the methods recently proposed by Sbafier and by Black bave ndded much to our facility in determining oxybutyric acid and appear to he very accurate.

The method which is here presented is exceedingly simple, requires little time, needs no elahorate chemical apparatus, and can be applied hy any general practitioner. It depends upon tbe following principles: The removal of acetone and diacetic acid by heat, the oxidation of $\beta$-oxyhutyric acid to acetone by means of hydrogen

1 Arch, f. exp. Path. u. Pharme, 1809-Band xlit.

Areh. f. exp. Path. u. Pharm., 1856, p. 21.

Ang, d. cbem., 1885, p. 228.

- Noth. Spec. Path. u. Ther., Band vii, 1, 181.

- treber den Einfluss de Alkalien auf d. mensch. Stoffer, Stuttgart, 1890.

- Arch. f. exp. Path u. Pharm. 1901. Band xlv

I Ztsehr. f. phyciol. Chem, 1901, Band xoxiti.

- nio Acetonkorper, Stuttcort. 1903, p. 38.

10 Jour. Biol. Chem., 1008, v, 211.

Ibid., I903, i, 37.

n Ibid.. 1908, v, 207. 
peroxide, and the detection of acetone in the urine thus treated by means of Lange's test.

By boiling the preformed acetone, dincetie acid and tbe volatile fatty acids are removed from the urine; the boiling must be continued long enough completely to remove all of these bodies, and the urine after such treatment should give a negative result with Lange's test. This test depends upon the property of urine containing acetone to develop a purplish red color when treated with glacial acetie acid; a few drops of a watery solution of sodium nitroprussiate, and ammonia. The reaetion is not given with alcohol or aldehyde; creatinin when present in considerable amounts gives a brownisl color, which, bowever, may be distinguished from the purplish red color of the acetone reaction.

To the urine from which acetone, diacetie acid, and the volatile fatty acids have been removed, but which still retains its $\beta-0 x y-$ butyrie acid, peroxide of hydrogen is added. By this means the $\beta$-axybutyric acid, as has been shown by Dakin, ${ }^{13}$ is oxidized to acetone. It may be noted that this cannot be a quantitative method, even in a rough degree, since Dakin has shown that the end-products of the oxidation of $\beta$-oxybutyric acid by peroxide of hydrogen consist of different substances varying in amount according to the course which the oxidation process takes, and is never acetone alone.

An abbreviated outline of the ehemical process involved may be represented by thesc formulie:

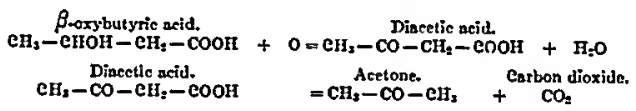

In the course of a study of the acetone bodies extending over a number of years I lare never found $\beta$-oxybutyrie acid in the urine unless a strong Annold's "reaetion and a strong ferric chloride reaction (Gerhardt's) were present. To a urine showing these renetions the test for $\beta$-oxybutyric acid may be applied in the following manner:

To 20 c.e. of the suspeeted urine add 20 c.c. of water and a few drops of acetic acid and boil until the volume is reduced to about 10 c.c. To this residue add water to the original volume (i.e., until it mensures 20 c.c.). Put this into two test-tubes (B and $C$ ) of equal size, 10 c.c. in eaeh test-tube. To onc of the test-tubes (C) add one cubic centimeter of peroxide of hydrogen, warm gently for about one minute (do not boil), and then allow the fluid to cool. Add to cacl test-tube (B and $C$ ) one-half of one cubic centimeter of glacial acetic acid and a few drops of a freshly prepared watery solution of sodium nitroprussiate and mix. Overlay the solution in cach test- 
tuhe with 2 c.c. of concentrated ammonium hydroxide. Allow these to stand for four or five hours, and at the end of this time compare the two test-tuhes. At the point of contact hetween the ammonia and the underlying fluid $B$ will show no ring (or a faint brown ring if much creatinin is present), test-tube $C$, to which hydrogen peroxide was added, will show a purplish red contact ring if $\beta$-oxybutyric acid was originally present; if $\beta$-oxyhutyric acid was not present, the two test-tuhes will not differ in appearance. If the two test-tubes are now shaken, the difference in color will he seen throughout the fluid; this difference is intensified hy allowing the tuhes to stand for fifteen or twenty minutes after shaking.

To detect slight differences in the color of the rings, the two testtubes should he held side hy side against a white backiground while the observer stands with his back to the light.

The oxidation hy means of hydrogen peroxide is gradual and rcaches its maximum in about four or five hours, af ter which the color slowly fades. When a very large amount of $\beta$-oxyhutyric acid is present the difference in the two test-tuhes may become evident in a few minutcs. It is always well to prepare the two test tubes as ahove for comparison. B will show whether all preformed acetone and diacetic aeid have heen driven off, and will also show the ereatinin ring (if present), so that its color may be compared with the color of the ring in tuhe $\mathrm{C}$.

The test may he applied to the urine either hefore or after fermentation; the presence of sugar does not interfcre with the reaetion. If alhumin is present it should be removed by filtration after the urinc has heen hoiled.

The method is moderately delicate and will certainly deteet $\beta$-oxybutyric aeid when present to the extent of $0: 3$ per cent. and prohably less.

The following tahle shows a number o urines in whieh the test, as ahove descrihed, showed a positive reaction for $\beta$-oxybutyrie acid in which the acid was quantitatively determined hy Shaffer's method.

\begin{tabular}{|c|c|c|c|c|c|}
\hline \multirow{2}{*}{$\begin{array}{c}\text { Specimen } \\
\text { number. }\end{array}$} & \multirow{2}{*}{$\begin{array}{l}\text { Levorotation } \\
\text { after fersentation. }\end{array}$} & \multirow{2}{*}{$\begin{array}{l}\text { Quantity in } \\
\text { 24 hotse, c.c. }\end{array}$} & \multicolumn{3}{|c|}{$\beta$-oxybutyric arid. } \\
\hline & & & $\begin{array}{l}\text { Total } \\
\text { Braunk }\end{array}$ & $\underset{\text { per iliter. }}{\text { Grams }}$ & Per cent. \\
\hline 1 & 0.7 & 4050 & 28.60 & 6.6 & 0.66 \\
\hline 2 & 0.7 & 2310 & 11.94 & 5.2 & 0.52 \\
\hline 3 & 0.5 & 1800 & 10.82 & 5.1 & 0.51 \\
\hline 4 & 0.6 & 1800 & 0.15 & 5.0 & 0.50 \\
\hline 5 & 0.5 & 4050 & 21.67 & 4.7 & 0.47 \\
\hline 0 & 0.5 & 2550 & 8.01 & 3.1 & 0.31 \\
\hline 7 & 0.2 & 3360 & 8.68 & 2.6 & 0.26 \\
\hline
\end{tabular}


That the test is somewhat delicate may he inferred from the fact that $I$ have ohtained it in a number of diahetic urines with a levorotation after fermentation of $\mathbf{0 . 2}$ and a ferric chloride reaction muels weaker than that given by any of the above urines in whieh the oxyhutyric acid was quantitatively determined. It has heen my cxpericnce that the amount of $\beta$-oxybutyric acid varies direetly (although not necessarily proportionately) with the amount of diacetic acid present and that the ferric chloride reaction varics dircetly in intensity with the amount of diacetic ac:d present. ${ }^{25}$

In a number of normal urines tested the reaction has not been obtained. It was also ahsent in a number of urines showing a weak ferric chloride reaction.

\title{
THE EFFEOT OF CERTAIN SO-CALLED MIIK MODIFIERS ON THE GASTRIC DIGESTION OF INFANTS.
}

\author{
BY T. Wơod Clarke, M.D.,

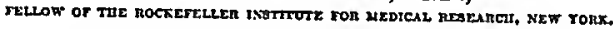 \\ 'From tho Wards of the Babies' Ilospital, Ner York, and the Chemiteal Laboratory of \\ the Rockefeller Institute for Mledical Research. New York.)
}

Is the fall of 1907 , at the instigation of Dr. L. Emmett Holt, investigations rere undertaken at the Rockefeller Institute in New York, in the hope of throwing light on some of the as yet obscure questions of infant digestion. The problem to he attacked was that of the digestion of milk in the infant's stomach, and more particularly the exact action of the more commonly used, so-called "milk modificrs," and their influcnce upon digestion both in health and disease.

A review of the literature of the gastrie digestion of the infant shows much valuahle work on its physiology and its variations according to age and health. It has heen shown that all the physiological factors oceurring in the adult stomach are present in the infant, but in weakcr form. It has further been proved that the younger the infant, the more active the motility of the stomach, that this motility is greater with woman's milk than with artificial food, and in health than in disease. It has heen proved that the acidity of the gastrie contents increases regularly after a meal for some time, but that free hydrochloric acid cannot he demonstrated for an hour or more after the ingestion of the food. This phenomenon has been shown to he due not to a lack of secretion of hydrochloric acid during the early stages of digestion, hut to the striking power which 